Golden Gate University School of Law GGU Law Digital Commons

\title{
The Inter-temporal Character of International and Comparative Law Regarding the Rights of the Indigenous Populations of the World
}

Sompong Sucharitkul

Golden Gate University School of Law, ssucharitkul@ggu.edu

Follow this and additional works at: http:// digitalcommons.law.ggu.edu/pubs

Part of the Comparative and Foreign Law Commons, and the Indian and Aboriginal Law Commons

\section{Recommended Citation}

50 Am. J. Comp. L. (suppl) 3 (2002)

This Conference Proceeding is brought to you for free and open access by the Faculty Scholarship at GGU Law Digital Commons. It has been accepted for inclusion in Publications by an authorized administrator of GGU Law Digital Commons. For more information, please contact jfischer@ggu.edu. 


\section{THE INTER-TEMPORAL CHARACTER OF INTERNATIONAL AND COMPARATIVE LAW REGARDING THE RIGHTS OF THE INDIGENOUS POPULATIONS OF THE WORLD}

SOMPONG SUCHARITKUL

Reprinted from

The American Journal of Comparative Law

Volume L (Supplement) 2002

Copyright $(2002$ by the American Society of Comparative Law, Inc. 


\section{The Inter-temporal Character of International and Comparative Law Regarding the Rights of the Indigenous Populations of the World}

\section{A Prelude to Further In-depth Studies}

This report explores ways and means in a selection of comparative legal systems to ensure adequate protection of the rights of indigenous peoples within the territorial confines of national jurisdictions. In most contemporary legal systems, attention has been drawn to the problems of how best to protect and safeguard the various fundamental rights of indigenous peoples of different tribes and denominations, co-existing in a single or multiple legal system. ${ }^{1}$ To ensure their survival and continued co-existence, not only their rights, but also their cultures, traditions, ways of life and civilizations, must be preserved intact as distinct but unique social, cultural, political and economic grouping within the same national community. ${ }^{2}$

Unwittingly or otherwise, the evolution of national legal awareness of the need for a contemporary society to provide reliable political, economic, cultural and social security safety nets for its indigenous people has contributed in no small measures to the grow-

Sompong Sucharitkul, D.C.L., D. Phil., M.A. (Oxon); Docteur en Droit (Paris); LL.M. (Harvard); of the Middle Temple, Barrister-at-law; Associate Dean and Distinguished Professor of International and Comparative Law, Golden Gate University School of Law, San Francisco, U.S.A. The author would like to express his gratitude to Professor Christian Okeke for his valuable suggestions and for presenting this report at the $16^{\text {th }}$ Congress of the International Academy of Comparative Law.

1. See Declaration on the Rights of Persons Belonging to National or Ethnic, Religious or Linguistic Minorities, G.A. Res. 47/135, 18 December 1992; U.N Draft Declaration on the Rights of Indigenous Peoples, U.N. Doc. E/CN.4/Sub 2/1994/2/Add 20 April 1994, and American Declaration of the Rights of Indigenous Peoples, OAS Declaration 1997 OAS. G.A.Res. OEA/Ser. P, AG/Doc. 3573/97 (1997). See also Falk, "The Right of Self-determination under International Law: The Coherence of Doctrine versus the Coherence of Experience," in Wolfgang Danspechgruber \& A. Watts (eds.), Self-determination and Self-administration 47 (1997), at 55, 61.

2. See Erica-Irene Daes, Protection of the Heritage of Indigenous People, A Report by the Special Repporteur of the Sub-Commission on Prevention of Discrimination and Protection of Minorities, Chairperson of the Working Group on Indigenous Populations, U.N., N.Y. \& Geneva 1997, Office of the High Commissioner for Human Rights, Study Series 10, 50th Anniversary of the Universal Declaration of Human Rights 1948-1998. See also the Report on the Working Group on Indigenous Populations for its $18^{\text {th }}$ session, Geneva, July 2001, E/CN.4/Sub.2/2000/24, 17 Aug. 2000, by President-Rapporteur, Miguel Alfonso Martinez and its Annexes. 
ing international consciousness of the imperative necessity to protect the precious cultures, traditions, ways of life and civilizations of every indigenous people in the world ${ }^{3}$ Inasmuch as it is desirable to preserve for succeeding generations the endangered species and the bio-diversity of the rich living resources of the sea, the land and the atmosphere, ${ }^{4}$ it is incumbent upon the current generation also to strive to protect the security, safety and social welfare of members of our own kind, the humankind, especially the indigenous peoples in each country.

In this connection, the progressive development of international law tends to reflect, if not in some instances to circumscribe, the material progress achieved in national communities. The interplay between national laws and the law of nations in legal development is worthy of the greatest attention. Any meaningful attempt to seek guidance to ascertain the appropriate direction in which to find practical and plausible ways and means to guarantee the continued co-existence of indigenous peoples as distinct social collectivities and autonomous communities within the national entities must be preceded by an endeavor to appreciate the inter-action between international and national policies and regulations, and the mutual enhancement of the degree of protection between national and minimum international or universal standards. It is in this domain that the study of comparative law is vital to the basic understanding of international legal developments. It will be seen how the use of comparative law techniques can serve to promote, reinforce and accelerate the process of crystallization of emerging norms of international law designed to

3. Henry J. Steiner \& Philip Alston, International Human Rights in Context (2nd ed. 2000). Note the existence of two binding instruments of general application to indigenous peoples: The 1957 ILO Convention No. 106 and ILO Convention No. 169 effective 1991. Work on the Draft Declaration on the Right of Indigenous Peoples of 1994 began in 1977 with the creation of the Working Group on Indigenous Populations of the U.N. Sub-Commission on Prevention of Discrimination and Protection of Minorities. A movement to recognize the interests of indigenous peoples has acted in earnest for the past 15 years. The right of indigenous peoples has since gained increasing recognition as distinctive communities deserving a special international law regime distinct from individual rights and the rights of minorities. Indeed, indigenous peoples often constitute minorities in a modern western style community, but indigenous peoples are not precluded from directing the administration of a country, nor from becoming majorities in a given society. On July 28, 2000, the United Nations Economic and Social Council decided to establish, by consensus resolution, a "Permanent Forum on Indigenous Issues" as a subsidiary organ of the Council. ECOSOC Res. $2000 / 22$.

4. See The U.S. Endangered Species Act of 1973, EAS (16 U.S.C.A. $\$ 1660$ to 1614), Renewable Resources Extension Act of 1978, RREA, (16 U.S.C.A. $\S 1671-1676$ ). On the international plane, See, for instance, The RIO Declaration on Environment and Development, Rio de Janeiro 1992 (27 Principles), The Washington Declaration on Protection of the Marine Environment for Land-based Activities, Washington 1995, as adopted on 1 November 1995, and Convention on Biological Diversity, entered into force from 29 December 1995 . For status of ratification, as of 10 July 1995, See UNEP Handbook of Environmental Law 271-74 (1999). 
preserve and protect the political, economic, social and cultural values of indigenous peoples populating the earth. On the other hand, adherence to generally accepted norms of international law will serve the cause of the indigenous peoples within any given national legal order.

A survey of general legal aspects and different dimensions of the subject of this report requires an initial and detailed systematic analysis and a thorough examination of a given situation leading to the consideration of substantive rights, individual and collective, which are specifically pertinent to ensure the healthful survival of indigenous civilizations. The present report is but a necessary prelude to further in-depth studies on the rights of the indigenous peoples.

In this report, certain basic questions will be addressed in order to pave the way to a better appreciation of the delicate and complex task ahead.

\section{The UsE OF Terms}

For the purpose of this report, as indeed for most other purposes, the first and foremost hurdle to overcome is the ascription of a precise meaning to the use of crucial terms, or a meaningful response to definitional questions. The Preamble of the San Francisco Charter of 1945 starts with the opening phrase "We the peoples. . ." The term "peoples" has never ceased to encounter countless difficulties in various contexts surrounding the right of self-determination of "peoples" within a national unit. All the more perplexing is this term "peoples" in regard to the right of secession, which is admitted as a collective constitutional right in some countries ${ }^{5}$ but is considered as undermining national territorial integrity of the federal union in others. ${ }^{6}$

5. See Article 70, 71 and 72, Chapter 8 of the USSR Constitution of October 7 , 1977, Novosti Press Agency Publishing House, Moscow (1977).

Article 70: "The USSR is an integral, federal, multinational State formed on the principle of socialist federalism as a result of the self-determination of nations and the voluntary association of equal Soviet Socialist Republics. . ."

Article 71 lists 14 units of the Russian Soviet Federal Socialist Republics.

Article 72 : "Each Union Republic shall retain the right freely to secede from the USSR."

As indeed in reality, the Soviet Socialist Republics did secede from the USSR upon its disintegration, namely Ukraine, Latvia, Lithunia, Estonia, Azerbaijan, Moldava, Kazakhstan, Georgia, Tajikistan, Turkmenistan, Krygyzstan, Armenia, Belarus, Uzbekistan. Chechnya, however, was not listed as a distinct member of the Union of the Soviet Socialist Republics.

6. The U.S. Constitution recognizes no such right or freedom for any state of the Federal Union to secede. For Reference re Secession of Quebec, see Opinion of the Supreme Court of Canada [1998] 2 S.C.R. 217, 37 Int'l Leg. Mat. 1342 (1998). The Supreme Court cited the Constitutional Act, 1876 as an act of nation-building and that federalism was the political mechanism by which diversity could be recognized with unity. The Constitution Act 1982 removed the last vestige of British authority and re-affirmed the country's commitment to the protection of its minority, to equality and to the fundamental freedoms as declared in the Canadian Charter of Rights and 
This marked absence of a generally accepted definition of the term "peoples" does not appear helpful to the search for an agreed use of the term "indigenous peoples".

Unless a clearer definition of "indigenousness" could timely be found, there would seem to be little or no likelihood of a generally accepted definition of "indigenous peoples". Indeed, the U.N. Draft Declaration on the Rights of Indigenous Peoples neatly managed to avoid any attempt to define the concept of "indigenous peoples". 7

Even without a precise definition or an express provision on the use of the term "indigenous peoples" in the present context, it is nonetheless useful, as an indication of a general notion or conception of the term, ${ }^{8}$ as used in an international instrument, such as the ILO

Freedoms. The Court observed that a right to secede 'unilaterally' is the right to effectuate secession without prior negotiation with the other provinces and the federal government. At issue is the legality of the final act of purported unilateral secession. "The federalism principle, in conjunction with the democratic principle, dictates that the clear repudiation of the existing constitutional order and the clear expression of the desire to pursue secession by the population of a province (even after a referendum procedure) could give rise to a reciprocal obligation on all parties to confederation to negotiate constitutional changes to respond to that desire. . . (para. 88)" The court thus disclaimed any supervisory role over the political aspects of constitutional negotiation. "Both the legality of the acts of the parties to the negotiation process under Canadian law, and the perceived legitimacy of such action, would be important considerations in the negotiations process. . (para. 103)" The Opinion cited relevant portions of international documents, including G. A. Resolution 50/6 of 9 November 1995 U.N. Declaration on the Occasion of the Fiftieth Anniversary which in Article 7 provides that the member States of the U.N. will continue to reaffirm the right of selfdetermination of all peoples. . This shall not be construed as authorizing or encouraging any action that would dismember or impair totally or in part, the territorial integrity or political unity of sovereign and independent States conducting themselves in compliance with the principle of equal rights and self-determination of peoples. . (para. 114). There is no necessary incompatibility between the maintenance of the territorial integrity of existing States, including Canada, and the right of a people to achieve a full measure of self-determination.

The Court noted, in paragraph 139, "However, the concern of aboriginal peoples is precipitated by asserted right of Quebec to unilateral secession. In lights of our finding. . that on the contrary a clear democratic expression of support for secession would lead under the constitution to negotiation in which aboriginal interests would be taken into account, it becomes unnecessary to explore further the concern of aboriginal peoples in this Reference."

7. See U.N. Draft Declaration on the Rights of Indigenous Peoples 20 April 1994 and the OAS draft cited in the note 1 above. The draft did not attempt to define indigenous peoples. The U.S. preliminary statement continued to resist the use of the term "peoples" in the plural, and the characterization of indigenous rights as collective right in both the U.N. and the OAS drafts. Brazil was equally reluctant to use the term "peoples" because of its association with the right of self-determination, which could entail the right to independent statehood and secession under international law, in the absence of any prohibition or authorization of unilateral secession by a people from within an existing sovereign and independent State.

8. Reisman, "Protecting Indigenous Rights in International Adjudication," 89 A.J.I.L. 350 (1995) refers to the "natives," "aborigines," or "indigenous peoples" as ones who were the time that proto-human bands roamed the wilds and lost, they either resisted organized peoples who invaded their inhabited territories, or were denied, assimilation and survived with a distinct, but not necessarily intact, cultural identity. The term has recently come to refer to a new pattern of claims, made by 
Convention on Indigenous and Tribal Peoples of 1989 (Convention No. 169$)^{9}$ to mention some of the criteria commonly used, namely aboriginality, cultural distinctiveness and self-identification ${ }^{10}$ as attributes of "indigenousness". ${ }^{11}$ The United Nations special Reporteurs appear to use the term with reference to those peoples who, "having a historical continuity with pre-invasion and pre-colonial societies, consider themselves distinct from other sectors of the societies now prevailing in those territories or parts of them. They form at present non-dominant sectors of societies and are determined to preserve, develop and transmit to future generations, their ancestral territories, and their ethnic identities, as the basis of their continued existence as peoples in accordance with their own cultural patterns, social institutions, and legal systems."12

The ILO Convention No. 169, in Article 1, stipulates that the Convention applies to " $(\mathrm{b})$ peoples in independent countries who are regarded as indigenous on account of their descent from the populations which inhabited the countries, or by geographic region to which the countries belong, at the time of the conquest or colonization or the establishment of present State boundaries and who, irrespective of their legal status retain some or all of their own social, economic, cultural and political situations." 13 Article 2 regards self-identification as indigenous or tribal as "a fundamental criterion for determining the group to which the provisions of this Convention applies." 14

these surviving indigenous peoples for direct protection by the international community and where appropriate, restoration of rights taken from them in the past.

9. See Leary, "Lessons From the Experience of the International Labour Organization," in The United Nations and Human Rights (P. Alston ed. 1992). Convention No. 169 entered into force in 1991, requiring "special measures" be adopted to safeguard indigenous interests, and recognizing the rights of ownership and possession of the peoples over the lands they traditionally occupy, and the right to retain their own customs and institutions not incompatible with fundamental rights.

10. See Swepston, "A New Step in the International Law on Indigenous and Tribal peoples: ILO Convention No. 169 of 1989," 15 Okla. City U. L. Rev. 677 (1990); see also 28 Int'l Leg. Mats. 1382 (1989).

11. See Barsh, "The World's Indigenous Peoples," White Paper Submitted to Calvert Group by First Nations Development Institute First Peoples Worldwide: also by the same author, "United Nations Seminar on Indigenous Peoples and States," 83 A.J.I.L. 599 (1989).

12. U.N. Special Reporteurs, José Martinez Cobo (1984) and Erica-Irene A. Daes (1994) identified the three components of "indigenous" as including "aboriginality," "distinctive culture" and "self-identification."

13. Article 1(3) provides that the "use of the term 'peoples' in this Convention shall not be construed as having any implication as regards the right which may attach to the term under international law". See also Barsh, "Indigenous Peoples in the 1990's: From Object to Subject of International Law?," 7 Harv. Hum. Rts. J. 33, 35 (1994).

14. Self-identification by the group or a member of the group is a useful prerequisite of indigenousness. Minorities and indigenous peoples form objects of separate international instruments. De lege ferenda, indigenous peoples are to be distinguished from minorities, although in many instances their rights are partially covered by the rights available for the protection of minorities. 
U.N. reports and other recent international instruments appear to relate more specifically to only one type of situations created by European invasion, conquest and colonization of territories occupied by indigenous populations of Northern and Southern American continents and the seizure of lands held by aboriginal tribes in Australia and New Zealand. In reality, the need to preserve indigenous social and cultural identities exists throughout the world. The problems encountered by indigenous peoples are far from uniform, ranging from international endeavors to salvage and maintain indigenous identities and cultures after years of alien domination or colonization by Western or European nations or by neighboring kingdoms, princedoms or tribesmen to national self-preservation in an effort to ward off or to pre-empt any display or threat of foreign superior force or authority. While numerous studies have been made in an effort to shed more light on the fate of indigenous populations in the United States, Canada, Latin America, ${ }^{15}$ Australia and New Zealand ${ }^{16}$ with comparable and contrasting approaches and varying degrees of success, very little or nothing has been published about indigenous civilizations in other parts of the world, such as Southeast Asia, China, Japan, the Indian sub-continent, the Pacific Islands, and Africa.

The conceptual and definitional deficiencies inherent in fractional and sectarian approaches to the problems confronting indigenous populations of the world will become more transparent, if we could extricate ourselves from the narrow confines of the societies in which we live. Indeed, the world itself has evolved through the passage of millions of years, witnessing the ever-changing faces of the earth and the evolutionary diversification of the human race and species. It has been suggested that all in all between 6,000 and 10,000 original cultures could be characterized as "indigenous," but most of them were absorbed by the growth of modern Nation-States ages ago. ${ }^{17}$ It is not always clear, noted one author, ${ }^{18}$ whether a particular group is an "indigenous" people or "minorities". The difference is per chance a matter of degree. ${ }^{19}$ China, for instance, has always recognized at various times, the existence within the Celestial Empire of

15. See, e.g., Roberts, "The Protection of Indigenous Population's Cultural Property in Peru, Mexico and the United States," 4 Tulsa J. Comp. \& Int'l L. 327 (1997); and Kreimer, "The Beginnings of the Inter-American Declaration on the Rights of Indigenous Peoples," 9 St. Thomas L. Rev. 271 (1996).

16. See generally Quentin-Baxter, "The U.N. Draft Declaration on the Rights of Indigenous Peoples - The International and Constitutional Law Contexts," 29 Victoria U. Wellington L . Rev. 85 (1999).

17. See Barsh, White Paper, supra n. 11.

18. Id. and also supra n. 14 .

19. Indigenous peoples may be in the majority, or in power for that matter, or they may be included within different "minorities." Members of the indigenous peoples should enjoy the protection designed for the indigenous population and yet not precluded from the enjoyment of minorities rights inasmuch as they may be partly entitled also to minorities rights. 
distinct "minorities", as much indigenous to Mainland China as the various Chinese ethnic groups themselves are aboriginal to East Asia.

(a) "Aboriginality" as a necessary criterion is not in itself free of imprecision. "Ab origine" means from the very beginning. Thus, an ethnic group that was first formed in a particular locality could be said to be aboriginal and thereby satisfies the test of aboriginality. This does not preclude the possibility of a multiplicity of different indigenous groups in one and the same geographical area or zone, which again through the passage of millennia and centuries may evolve or change its characteristics or its dimension or geographical contour beyond recall, recollection or even recognition. For these reasons, "aboriginality" as a criterion is relative to the time frame within which the term is used. ${ }^{20}$

(b) "Cultural Distinctiveness" is another criterion that deserves particular attention. Distinctiveness of a culture could in time fade out or dissipate for various reasons due to the need or desirability of assimilation or merger with another equally distinctive culture, thereby losing its original uniqueness. Cultural distinctiveness has its beginning, i.e., its aboriginality, but it could also fall into oblivion or desuetude, out of vogue or fashion, losing its originality or blurring its uniqueness. ${ }^{21}$

(c) "Self-identification" constitutes a formal test. If, and as long only as a group continues to identify itself as an "indigenous" group, its "indigenousness" is established and maintained unchallenged. $R a$ tione cessante, whenever the group ceases to identify itself as such, it no longer retains its "indigenousness" and becomes blended with or assimilated to the massive members of the society in which the group has been integrated. Therefore, this last criterion also is coterminous with a time-frame, outside of which it no longer exists or ceases to exist as a distinctive indigenous people. ${ }^{22}$

20. See generally Lokan, "From Recognition to Reconciliation; The Functions of ABORIGINAL Rights Law," 23 Melbourne U.L.R. 65 (1999). The term 'aborigines' is used, depending on the context, to refer to either the indigenous peoples of Australia, the indigenous peoples of Canada, or indigenous peoples in general. See also Van der Peet [1996] 2 SCR 507, 562: "Aboriginal rights arise from the prior occupation of land, but they also arise from the prior social organization and distinctive cultures of "aboriginal peoples on that land."

21. See Van der Peet [1996] 2 SCR 507, 562: “. . .courts must look at both the relationship of an aboriginal claimant to the land and at the practices, customs and traditions arising from the claimant's distinctive culture and society."

22. Id. "Courts must not focus so entirely on the relationship of aboriginal peoples with the land that they lose sight of the other factors relevant to the identification and definition of aboriginal rights." See the U.N. Committee on the Elimination of Racial Discrimination ('CERD'), Findings on the Native title Amendment Act 1998 (th), U.N. Doc. ERD/c/54/misc. 40/Rev.2 (18 March 1999). 


\section{The Changing Political Geography of the Globe}

Most commentators on indigenous heritage ${ }^{23}$ and the rights of indigenous peoples ${ }^{24}$ recognize the political vicissitudes which materially affect the transfer of territories and modification or rectification of national boundaries. The map of the globe today is not the same as yesteryear. Indeed, the world map has undergone innumerable changes, including succession of states, disintegration of sovereign nations, merger and unification of states, annexation of territories. Changes in national frontiers and boundaries have been matters of frequent if not intermittent occurrences. New countries are both created, established or dissolved, dismantled and removed from the geographical coordinates wherein they used to be situated. These are natural phenomena of the changing face of the surface of the earth, thanks to the events that have taken place with the cycle of war and peace or relative peacefulness and continual state of international and internal armed conflicts, resulting in territorial alteration and modification of national landscapes. ${ }^{25}$

The names of the countries are usually associated with their geographical location and dimension. Geography, at any rate, political geography, as reflected in the boundary making and delimitation of frontiers, territorial, maritime and aerial or atmospheric, changes with time. It is therefore only pertinent that any reference to a particular locality or country for purposes of protection of indigenous rights or cultural heritage must be qualified by the time element or the time frame within which to engage a meaningful discussion. ${ }^{26}$

Europeans are aware of the changing frontiers of Europe. Belgium, Austria, Switzerland, Italy, the Federal Republic of Germany and Former Yugoslavia provide ample evidences of fluctuation in place names, country denomination and boundaries. ${ }^{27}$ Asians are

23. For the meaning of "heritage," Erica-Irene A. Daes in her report on the "Protection of the Heritage of Indigenous People," U.N., N.Y. and Geneva, 1997, defines the term as "everything that belongs to the distinct identity of a people and which is theirs to share, if they wish, with other peoples. . the creative production of human thought and craftsmanship, such as songs, stories, scientific knowledge and artworks. . . inheritances from the past and from nature, such as human remains, the natural factors of the landscape, and naturally-occurring species of plants and animals with which the peoples have long been connected".

24. See generally Donald Craig Mitchell, Sold America: The Story of Alaska Na. tive and Their Land, 1867-1959 (1997); and "Alaska v. Native Village of Venetie: Statutory Constitution or Judicial Usurpation? Why History Courts," 14 Alaska L. Rev. 353 (1997).

25. See Arsanjani, "Environmental Rights and Indigenous Wrongs," 9 St. Thomas L. Rev. 85 (1960, and Triggs, "Australia's Indigenous Peoples and International Law: Validity of the Native Title Amendment Act 1998," 23 Melbourne U. L. Rev. 372 (1999).

26. See generally Reisman, supra n. 8 .

27. With the advent of the disintegration of the Union of Soviet Socialist Republics and Former Yugoslavia, Europe has seen the rise of new members. See note 5 above. 
fully cognizant of the differences or absence thereof between Siam and Thailand, Cambodia and Kampuchea, Burma and Myanmar, Laos and Siam Lao, Vietnam (North, South and Vietcong) and Korea (North and South). ${ }^{28}$ Africans on the other hand are getting used to new names for older nations such as Ethiopia, Abyssinia, the Gold Coast, Nigeria, Niger, Cameroon, Burkina Faso, Mali, Gambia, Zambia, Zaire, Zimbabwe, etc. ${ }^{29}$ The list continues. ${ }^{30}$

It is not practical, nor indeed desirable to evaluate the status of the indigenous peoples within the territorial confines of a given nation or State without delineating the relevant time frame. The temporal dimension is essential to any useful discussion of the need to protect the rights and heritage of the peoples who are considered to be indigenous to the area, as a geographical unit at a given time, within a designated time slot. 31

\section{Demographic Distribution and Voluntary Movements of Global Populations}

Regardless of the relativity of war and peace, indigenous, tribal and aboriginal populations have freely moved from one geographical location to another. Indigenous peoples including the Nomadic tribes have moved about, back and forth, and relocate in massive population transfer more or less freely of their own volition, in search for better environments, milder climate, greater abundance of water and food supplies or for any other reason. ${ }^{32}$ As long as peoples live in a social group or a community, there is always an opportunity to look for a better place to farm, to fish, to hunt or to settle on more fertile soil within friendlier or less hostile surroundings. This is a natural phenomenon in demographic displacement. ${ }^{33}$

When an indigenous population moves from its former habitat to another location where there are no other former inhabitants, the

28. See The U.N. Transitory Authority for East Timor. See also Ntumy, "The Protection of the Ethnic autonomy of Kanaks in New Caledonia," 10 UCLA Pac. Basin L. J. 376 (1992).

29. See Barsh, White Paper, supra n. 11; ". . Africans consider themselves indigenous peoples who have achieved decolonization and self-determination".

30. Id. "Yet many relatively small nomadic herding and hunter-gatherer societies such as the Thareg (Niger), Maasai (Kenya), Mbuti (Congo) and San (Southern Africa's Kalahari have been displaced and oppressed (internally colonized) by ethnically unrelated African peoples who have been their neighbours for a thousand years and longer".

31. See, for instance, a case note by Barnett, "Western Australia v. Ward: One Step Forward and Two Steps Back: Native title and the Bundle of Rights Analysis," 24 Melbourne U. L. Rev. 462 (2000).

32. See, for instance, Western Sahara Case 1975 ICJ Rep. 12 (Advisory opinion of Oct. 16).

33. See, for instance, the Gulf of Fonseca Case, 1992 ICJ Rep. 351 (Sept. 11) between El Salvador and Honduras, Nicaragua intervening with the Court's permission. The case related to earlier rights of "Indian poblaciones" and the settlement by the 1980 peace treaty ending the Soccer War of 1969. 
original group does not lose its indigenous character, as it retains its aboriginality in connection with the newfound territory which could literally be regarded as "no man's land" or "terra nullius". ${ }^{34}$ It could also happen that one indigenous group moving out of its place of origin into a new territory may encounter yet another distinctive aboriginal group indigenous to that newly chosen territory. ${ }^{35}$ Negotiations could ensue, leading to an amiable settlement or an armed conflict or confrontation could break out requiring resolution by means that could be short of the use of force. ${ }^{36}$

Apart from the movements of nomadic hill tribes and tribesmen in the desert such as the Sahara, there have been massive movements of peoples indigenous to Asia and the Pacific, notably Chinese, Indians, Mongolians, Iranians, Persians, Eskimos, Israelites, Malays and Polynesians. ${ }^{37}$ These ethnic groups are indigenous to their homelands but in their newfound land or island of their choice, they are not indigenous. They are no longer aboriginal, but are visitors, immigrants or invited guests of the original native born groups. Clearly, the Chinese in San Francisco or the Thais in Los Angeles are not aboriginal, nor indigenous to California. They are nonetheless indigenous to China and Thailand respectively despite their becoming Asian minorities or Californians. ${ }^{38}$ In the United States, Chinese and Thais are not indigenous and should not be treated as such, while native Americans or American/Canadian Indians of various tribes and denominations should be so treated with due respect to their cultural heritage and indigenous rights in the United States as to a greater or lesser degree also in Canada. ${ }^{39}$

As has been abundantly demonstrated, the relativity of "indigenousness" has been caused by the voluntary migration or movements of populations from their place of origin or homelands to their new places of adoption. The treatment of a single indigenous population, such as the Chinese or overseas Chinese affords an interesting com-

34. The Eskimos, the Mongolians and the Alaskans moved about freely not only in the northern region but also in the Pacific.

35. Pacific Islands, including Japanese, Taiwanese, Okinawan, etc., have received many waves of visitors.

36. Southeast Asia has afforded fertile ground or Promised Land, land of opportunities for many immigrations from without. See also Kingsbury, "Indigenous People, in International Law; A Constitutionist Approach to the Asian Controversy," 92 A.J.I.L 414 (1998).

37. There are overseas Chinese and overseas Indians, especially in Southeast Asia and the Pacific from time immemorial.

38. Asians in the United States are classified, depending on the origin or the period, as Chinese, Pacific Islanders or simply Asians.

39. The term "Indians" have different meaning, depending on the usage. In the Americas, it refers to Native Americans of various tribes. In Asia and Africa, it refers to population indigenous to the Indian Subcontinent. The term "East Indies" and "West Indies" refer to different ethnic groups. "East Indies" are Indonesian, Javanese, Balinese, Sumatrans etc., while "West Indies" are the islanders in the Caribbean imported by England. 
parison or contrast from one country-study to another, from one legal system to the next. As minorities, the Chinese are accorded certain minorities rights in various states of the United States and Canada. In Thailand, they have been assimilated in accordance with a national policy adopted by King Chulalongkorn almost a century and a half ago with full rights and titles as Thai subjects, while maintaining their respective traditional ethnic Chinese ancestry. ${ }^{40}$ In Malaysia, a new national policy of "Bhumi Putra", literally children of the land, has been implemented with the result that non-native Bhumi Putra without discrimination, Chinese or Indian alike, enjoy less than the equal protection, equal rights and privileges accorded to Malay "Bhumi Putra". ${ }^{41}$ The application of new laws and regulations regarding the protection of indigenous rights by the homeland itself must be viewed and tested within a time-limit or a period of time when the indigenous rights are recognized and protected by the home state as against further encroachments by outsiders not only, as measures of self-protection but rather as the duty to preserve their indigenous heritage.

The above category of cases must be contrasted with the more unenviable cases of Western expansionism in the new world, in Asia and in Africa, especially in the societies where the surviving indigenous populations continue to subsist under the governance, if not domination, of their uninvited European or Western intruders. ${ }^{42}$ According to the voices of these indigenous peoples heard in the forums of international human rights within the framework of the United Nations, they would like to have their collective indigenous rights recognized as such in the first place..$^{43}$ Secondly, they would like to have their territorial rights restored and their land returned. ${ }^{44}$ Thirdly, they would like to have their right to self-determination as an autonomy or a self-government ${ }^{45}$ within the established community. Fourthly, they would like to have their legal status recognized by the international community. ${ }^{46}$ These are four of the initial concerns voiced by or on behalf of the indigenous peoples in the United

40. See part VII infra.

41. The precise definition of "Bhumi Putra" remains to be worked out through the process of judicial interpretation, which increasingly is shifting from English to Malay as the principal official language of the law and the courts.

42. See Roberts, supra n. 15.

43. Williams, "Encounters on the Frontier of International Human Rights Law: Redefining the Terms of Indigenous Peoples' Survival in the World," 1990 Duke L. J. 660 (1990).

44. See generally Morse, "Common Roots but Modern Divergencies: Aboriginal policies in Canada and the United States," 10 St. Thomas L. Rev. 115 (1997).

45. See generally Suagee, "Human Rights of Indigenous People: Will the United States Rise to the Occasion?," 21 Am. Indian L. Rev. 365 (1997).

46. See, for instance, the Indigenous Peoples' Seattle Declaration on the Occasion of the Third Ministerial Meeting of the WTO November 30-December 3, 1999, available at, http://www.ldb.org/indi99.htm. 
States, Canada and Australia. It will be seen how step-by-step these concerns have been or are being addressed in comparatively different forms and measures in the three common-law systems concerned. ${ }^{47}$

\section{Indigenous Rights at Their Best Where National and International Legal Systems Meet}

If in the better known examples of the indigenous peoples in the United States, Canada and Australia, their plights have received public notice and national as well as international attention with a remote chance of continuing gradual improvements of their lot, the evolution of national positions appears to an appreciable extent to have been prompted by the loud outcries from these vocal indigenous populations themselves in national, regional and international forums. ${ }^{48}$ It should not be forgotten that international law, or the then prevailing European generated law of nations, has provided some fragile legal basis for the original deprivations of their pre-existing inherent rights as independent sovereign nations and peoples. ${ }^{49}$

By way of illustration, Chief Justice John Marshall in Johnson $v$. M'Intosh (1823) ${ }^{50}$ elaborated the doctrine that the invading European acquired exclusive rights and control over the territories they discovered in spite of the subsisting occupation by the indigenous Native Americans. Upon discovery, the sovereign rights of the indigenous populations were necessarily curtailed ${ }^{51}$ and their power to dispose of the land at will was denied while their territories under their timehonored occupation were regarded as "terra nullius" or " no man's land" open to usurpation and acquisition of new title by mere dispossession. Even for "terra nullius", Max Huber decided in the Island of Palmas case $1928^{52}$ that it could never be acquired by discovery alone. Discovery merely gives an inchoate title which has to be followed up by effective occupation involving consistent and sustainable display of sovereign authority. 53

47. See sections $V$ and VI infra.

48. See generally Kaon-Cohen, "Native Justice in Australia, Canada and the U.S.A.: A Comparative Analysis," 7 Monash U. L. Rev. 250 (1981).

49. See generally Bravo, "Balancing Rights to Land and the Demands of Economic Development: Lessons from the United States and Australia," 30 Colum. J. L. \& Soc. Prob. 529 (1997).

50. 21 U.S. ( 8 Wheat) 453 (1823). The dispute related to land purchased from the Indian, now Illinois.

51. Id. at 272-74. The European discovery doctrine gave exclusive right and control to the European explorers over the land and the people occupying.

52. See Huber, "Sole Arbitrator in the Island of Palmas Case. U.S.A. v. Netherlands," P.C.A. (1928) 2 U.N. Rep. Int'l Arb. Awards 829.

53. See Robert Jennings, Acquisition of Territory in International Law (1963). The Arbitrator Huber cited Rhode Island v. Massachusetts, 4 U.S. 591 (U.S. 1845), and Indiana v. Kentucky, 136 U.S. 479 (1890). See Jessup, 22 A.J.I.L. and Johnson, "Constitution as a Root of Title in International Law," 1995 Cambridge L.J. 215 (1955). 
In Cherokee Nation v. Georgia (1831) ${ }^{54}$ Chief Justice Marshall, relegating the status of American Indians to "domestic dependent nations", denied their standing to bring suit in a U. S. court, but would advise the Indians to appeal to the tomahawk. ${ }^{55}$ In the last case of the Marshall trilogy, Worcester v. Georgia (1832) ${ }^{56}$ some protection was afforded to the Cherokees. The Supreme Court struck down the Georgian statute designed to destroy the Cherokee's political community and possession of their land. Native Indian sovereignty was recognized and legal consent was required to extinguish native title of the Indians. This decision appeared promising but in practice yielded no positive results, since it lacked the executive power of enforcement. ${ }^{57}$

If Chief Justice Marshall had tried unsuccessfully to apply a brake to the European doctrine of discovery by recognizing the existence of treaty rights conceded by the United States Government, the United States Supreme Court in the last three decades has consistently upheld the absolute plenary power of the federal government over Indian Affairs, including authorization to destroy Indian religious sites and practices, to suppress traditional forms of tribal government, forcibly to remove Indian children from their homes, without payment of compensation to take resources, and to induce involuntary sterilization of indigenous Indian women, among other genocidal and ethnocidal ventures. ${ }^{58}$

Stripped of all collective rights as indigenous populations without traditional territorial links, or any right of self-determination or the slightest international legal status, native Americans in the United States and in Canada have not been able to avail themselves of their treaty rights on the ground that under international law indigenous parties were devoid of any treaty-making capacity attributable to independent sovereign nations and peoples. ${ }^{59}$ The United States and Canadian laws relying on Eurocentric international law have failed to recognize the validity of treaties with native North

54. 30 U.S. (5 Pet.) 1 (1831).

55. Id. at 18.

56. 31 U.S. (5 Pet.) 515, 542, 543 (1832). Marshall refined his characterization and described the Indian tribe as "distinct peoples, divided into separate nations, independent of each other, and of the rest of the world, having institutions of their own and governing themselves by their own laws."

57. The Worcester decision was never enforced, and the Cherokees were forced off their land across the Mississippi. See Russell, "High Courts and the Rights of Aboriginal Peoples: The Limits of Judicial Independence," 61 Sask. L. Rev. 247, 267 (1998), at 251-52.

58. See the United States v. Sioux Nation of Indians, 448 U.S. 37 (1980) and the Lone Wolf case, 187 U.S. at 568.

59. The Transfer of Indian Claims from the Indian Claims Commission (ICC) to the Court of Claim in 1978 and no longer compensable hereunder. Unlike treaties recognized in treaties and other agreements, native title was not compsenable under the takings clause of the Fifth Amendment. 25 U.S.C $\$ 70 \mathrm{v}$ (1978). 
American Indians as of any value beyond contracts of private law character unenforceable against the unwilling authority of the political branch of the government. ${ }^{60}$

The survival of the indigenous peoples of North America and the continued subsistence of the aboriginal peoples of Australia would depend in large measures on the generosity and mercy of the prevailing authorities of the European settlers. The political will to abide by the national laws which could improve from total disregard of any indigenous rights to gradual recognition and readiness to implement some of the measures in support of the indigenous heritage ${ }^{61}$ Further improvements on the national legal fronts will depend largely on positive progressive developments of international law setting general minimum standards designed to preserve and protect the traditional values and cultural heritage of the indigenous peoples. ${ }^{62}$ It is possible for international law to become more internationalized and better humanized in favour of the indigenous communities with the view, in the ultimate analysis, to inducing more beneficial national legislation to give effect to international aspirations. ${ }^{63}$ The sooner the meeting could be arranged between national and international legal doctrines, the happier will appear to be the indigenous populations on this earth. The meeting or increased overlap between the international legal order and the various national legal systems will contribute to the improvement of the climate that fosters greater protection of indigenous rights. ${ }^{64}$

\section{National Acceptance of International Standards}

A comparative study of the practice of Canada and of the United States in a pair of parallel cases involving a claim or claims of indigenous Canadian and American Indian women to have their pre-marital indigenous status and rights restored will illustrate the relative ease with which in Canada, where the possibility exists for individual petition under the International Covenant on Civil and Political Rights of $1966^{65}$ and its Protocol, an aggrieved native Canadian

60. See Cross, "Sovereign Bargains, Indian Takings, and the preservation of Indian Country in the Twenty-First Century," 40 Ariz. L. Rev. 425, 431 (1998), a shift from an Indian 'trading' to an Indian 'raiding' strategy as a more sufficient means of acquiring Indian Lands, at 455.

61. See Triggs, "Australia's Indigenous Peoples and International Law: Validity of the Native Title Amendment Act, 1998," 23 Melbourne U. L. Rev. 372 (1999), and supra n. 25.

62. See Anaya, "Indigenous Peoples, International Law Issues, 92 Proceedings of the Annual Meeting," ASIL 96 (1998).

63. See Green, "Aboriginal Peoples, International law and the Canadian Charter of Rights and Freedom," 16 Canadian Bar Review 113 (1982).

64. See generally Maritza Pena Guzman, "The Emerging System of International Protection of Indigenous Peoples' Rights," 9 St. Thomas L. Rev. 251 (1996).

65. Dec. 16, 1966, G.A. Res. 2200 A (xxi), 21 U.N. GOAR Supp. (No. 16) at 52, U.N. Doc. A/6316 (1966) 999 UNTS 171 entered into force March 231976. 
American Indian could successfully vindicate her indigenous rights. Once the home State is willing to accept international standards, effective ways and means can be found through the U.N. Human Rights Committee to have her complaint against discrimination based on gender heard and resolved.

Thus, in Lovelace v. Canada (1981), 66 Sandra Lovelace submitted a communication, stating that she was a 32 year-old-woman, living in Canada, born and registered as "Maliseet Indian" but has lost her rights and status as an Indian in accordance with section 12 (1) (b) of the Indian Act of Canada, after having married a non-Indian on 23 May 1970. However, an Indian man marrying a non-Indian woman does not lose his Indian status. The Indian Act therefore violates article 2 (1), 3, 23 (1) and (4), 26 and 27 of the Covenant of 1966. In its submission, Canada the State party recognized that "many of the provisions of the Indian Act, including section 12(1) (b) require serious reconsideration and reform. The Committee observed that $\mathrm{Ca}$ nada had undertaken under Article 2(1) and (2) of the Covenant to respect and ensure to all individuals within its territory and subject to its jurisdiction, the rights recognized in the Covenant without distinction of any kind such as gender, and to adopt the necessary measures to give effect to these rights." The Committee further observed that "the major loss to a person ceasing to be an Indian is the loss of the cultural benefits of having Indian Community, the emotional ties to home, family, friends and neighbours, and the loss of identity."67 Accordingly, the Committee acting under Article 5(4) of the Optional Protocol is of the view that the facts of the present case, which establish that Sandra Lovelace has been denied the legal right to reside in the Tobique Reserve, disclose a breach by Canada of article 27 of the Covenant. ${ }^{68}$ On July 28, 1985 the Indian Act amendment (S.C. 1985, C. 27) came into force in Canada. The amended Act omitted section 12(1) (b), which prescribed that Indian women marrying non-Indian lose their Indian status. It allowed registration of Indians who previously lost their Indian status under the repealed section of the Indian Act. As a result of the amendment, 24,000 persons regained indige-

66. See Communication No. 24/1977 by Sandra Lovelace on 29 December 1977 and Views by the Human Rights Committee on 30 July 1981 (thirteenth session), Report of the HRC, 36 U.N. GOAR Supp. (No.40) at 166, U.N. Doc. at 36/40 (1981).

67. See Lovelace case as reported and commented in Frank Newman and David Weissbrodt, "International Human Rights," second printing Aug. 1991. pp. 75-84.

68. Article 27 provides: "In these States in which ethnic, religious or linguistic minorities exist, persons belonging to such minorities shall not be denied the right, in communities with the other members of their group, to enjoy their own culture, and to practice their religion, or to use their own language. 
nous rights and Indian Status. ${ }^{69}$ This amendment also served to avoid violating section 15 (1) of the Charter of Rights and Freedoms. ${ }^{70}$

A way was found and a means adopted for Canada to right the wrongs suffered by 24,000 married Indian women whose indigenous status has since been resuscitated. ${ }^{71}$ Without the U.N. Human Rights Committee as a body responsible for hearing communications and stating its views, and without the good faith and willingness of the Canadian Government to accept international standards, the plight of the 24,000 married Indian women in Canada would have remained unattended let alone resolved. ${ }^{72}$

The Canadian case of Sandra Lovelace is to be contrasted with the U.S. case of Martinez in Martinez v. Santa Clara Pueblo (1976). ${ }^{73}$ This case concerned the validity of a membership ordinance of Santa Clara Pueblo in New Mexico. The appellants are female members of the Pueblo who, not unlike Lovelace in Canada, are married to nonmembers, together with their children. The ordinance grants membership of the Pueblo to "all children born of marriages between male members of the Santa Clara Pueblo and non-members" but precludes membership for "children born of marriages between female members of the Santa Clara Pueblo and non-members"74 In the Trial Court the decision was in favour of the defendants. ${ }^{75}$ The Supreme Court in 1978 reversed the 10th Circuit, declining jurisdiction over complaints under the Indian Civil Rights Act (25 U.S.C. $\$ 1302$ ) and dismissed the case without discussing the merits, ${ }^{76}$ except finding in the legislative history a desire to protect Indian self-determination. The Supreme Court reasoned that Congress intended that such suits be heard in tribal fora that are better suited to evaluate questions of tribal tradition, ${ }^{77}$ thereby abdicating its responsibilities to promote

69. See Opekokew, "Self-Identification and Culture Preservation: A Commentary on Recent Indian Act Amendments," 2 Canadian National Rep. 1, $2-5$ (1986).

70. See Canadian Charter of Rights and Freedoms, 1981, section 15(1), 27 and 28.

71. Although Lovelace case was an individual petition under article $5(4)$ of the Optional Protocol, the views of the Committee not only prompted the adoption of the 1985 Amendment but also enabled the registration of 24,000 Indians otherwise previously deprived of their Indian status.

72. Compare and contrast the Martinez case in paragraph 33 below. Compare also the decision of U.N. CERD regarding Australia's violation of International obligations in regard to the Amended Native Title Act, 1998 (18 March 1999). See also paragraph 34 of the Alfonso Martinez Report, E/CN.4/Sub.2/2000/24, p. 9 in supra n. 2.

73. See Doyle, Circuit Judge 540 F. 2d. 1039 (10th Cir. 1976).

74. Appellants alleged that the ordinance contravenes the equal right protection and due process provisions of the Indian Civil Rights Act of 1968, 25 U.S.C. Section 1302(8).

75. 402 F. Supp. 5 (D.N.M. 1975)

76. Santa Clara Pueblo v. Martinez 436 U.S. 49 (1978).

77. See Justice Doyle in the 10th Circuit, 540 F. 2d 1039 (1996): "In sum, if they were to approve the ordinance and in turn approve this plain discrimination, it would be tantamount to saying that the Indian Bill of Rights is merely an abstract statement of principle. 
equal protection to female members of Santa Clara Pueblo marrying non-members and their offsprings. The children of Julie and Myles Martinez are 100 percent Indian and 50 percent Santa Claran, speaking the language of the Santa Clara Pueblo, namely Tewa. They practice the customs of the tribe and are accepted into the tribe's religion. Nevertheless, membership is denied and they stand to be excluded from the band with the right of inheritance, residency and voting, solely because their mother rather than their father is a Santa Claran. ${ }^{78} \mathrm{Had}$ this occurred in Canada, or in the United States after the latter's ratification of the International Covenant on Civil and Political Rights, the acceptance of the U.S. Government of international standards could provide a positive solution, notwithstanding the effect or absence thereof of the U.S. ratification of the Covenant. ${ }^{79}$ The equal protection clause of the U.S. Constitution and the U.S. acceptance of international standards of non-discrimination based on gender might supersede, if not override any suggestion of the supremacy or unquestionable validity of the ordinance of an otherwise autonomous indigenous community. ${ }^{80}$

\section{The Role of the Judiciary in the Meaningful INTERPRETATION AND EFFECTIVE IMPLEMENTATION OF Progressive National Legislation}

The United Nations proclaimed $1993^{81}$ the International Year of the World's Indigenous Peoples and the General Assembly had earlier ushered in the International Decade of the World's Indigenous Peoples for 1990-2000. ${ }^{82}$ An interesting comparative analysis can be made of progressive legal developments in the United States and Australia in respect of the treatment of Native titles and the indigenous peoples' right to land. In this connection, the judiciary in each of the countries under review may be said to have played a decisive role, reflecting its willing determination or reluctance to give effect to national legislation and to provide a meaningful interpretation to its revealing provisions.

78. Id. The Circuit Judge did not think that the Fourteenth Amendment standards of equal protection, however, apply with full force. They do nevertheless serve as persuasive guide to the decision. The Indian Bill of Rights is modeled after the Constitution of the United States and is to be interpreted in the light of Constitutional Law decisions.

79. See Shelton, "International Law," in U.S. Ratification of the International Covenant on Human Rights, 27, 29-33 (Hurst Hannum \& Dana D. Fischer ed., 1993).

80. In any event, the U.S. Senate's advice and consent is subject to the Declaration that the provisions of Article 1 through 27 of the Covenant are not self-executing. 138 Cong. Rec. S 4781-01 (daily ed., April 2, 1992).

81. G.A. Res. 51/78, U.N. Doc. A/Res/51/78 (1997). See Amy Sender, Australia Example of Treatment Towards Native Title: Indigenous People's Land Rights in Australia and the United States.

82. G.A. Res. 45/164, U.N. Doc A/Res/45/164 (1991). 
The theory of "terra nullius" was applied by the British and subsequently by the United States Supreme Court in as early as 1823 in Johnson v. M'Intosh. ${ }^{83}$ England proclaimed Australia as British territory in $1788^{84}$ and successively expanded thè doctrine of "terra nullius" to later annexations such as the Murray Islands in $1879^{85}$ at the expense of the original inhabitants under the pretext that the primitive aboriginal population did not display any evidence of clearly identifiable laws and definitive titles to land. 86 Thus, the adoption of Pacific Islander Acts, $1872^{87}$ and $1875^{88}$ made no provision for the continued existence of native titles. As late as 1971, in Milirrpum $v$. Nabalco Pty. Ltd., 89 the Yirrkala aborigines of the Gove Peninsula in the Northern territory of Australia were denied judicial recognition of their right to stop bauxite mining taking place on their land and no compensatory damages were awarded, Justice Blackburn holding that Australia did not recognize communal native title, the Yirrkala aborigines did not have continual connection to the land since 1788 and that their relationship did not create a proprietary right. ${ }^{90}$

A significant change of judicial position took place in Mabo $v$. Queensland (1992) ${ }^{91}$ after ten years of litigation, the High Court of Australia in a 6 to 1 decision overruled Justice Blackburn's decision in Milirrpum case, ${ }^{92}$ in effect, recognizing native title. This decision is of general application and is not limited to the Meriam Aborigines in the Murray Islands, and that aboriginal and indigenous rights and titles survived annexation which did not operate to extinguish their claims. This case is a clear precedent for the biological descendents of the aboriginal inhabitants of the Murray Islands who maintained their customs and traditions. Other aboriginal groups might encounter other obstacles in the presentation of their respective claims. To put the treatment of aboriginal rights on a more clearly ascertainable basis, Australia passed the Native Title Act of $1993^{93}$ to validate all

83. 21 U.S. (8 Wheat) 534 (1823).

84. See Bravo, "Balancing Indigenous Rights to Land and the Demands of Economic Development, Lessons from the United States and Australia," 30 Colum. J. L. \& Soc. Probs. 529, 531 (1997).

85. See Mabo, 107 A.L.R. at 1, 10.

86. See Manwaring, "Recent Development," 34 Harv. Int'l. L. J. 177, 177 n. 1 (1993). Indeed, such aboriginal inhabitants were not of a sufficient level of civilization to "own" the land effectively, or that the territory is practically unoccupied. See Mabo, 107 A.L.R. at 4.

87. 35 \& 36 Vict. Ch. 19 (Eng.).

88. 38 \& 39 Vict. Ch. 51 (Eng.).

89. (1971) 17 F.L.R. 141 (Aust1.).

90. See Mabo, 107 A.L.R. at 77.

91. (1992) 107 A.L.R. 1 (Austl.). Since Australia's acceptance of the Protocol, the U.N. Committee on the Elimination of Racial Discrimination (CERD) has been invoked and may continue to be invoked by Australian indigenous tribes against the Australian Government for violation of international treaty obligation.

92. See supra n. 89 .

93. See Native Title Act, $\$ 15(1)(b)(i i), \$ 26-42$, and $\$ 107-110$. 
prior acts where native titles were under sole ownership of non-natives. Thus, claimants are not entitled to compensation if their title was extinguished after the Commonwealth's Racial Discrimination Act of $1975^{94}$ as long as proof was furnished of their connection with the land at annexation. A National Native Title Tribunal was created to serve as a mediating body to hear and process native title claims and fund programs to assist disputes over native titles. Although comprehensive, the National Native Title Act did not address the question of pastoral leases. The High Court in Wik People v. Queensland $(1996)^{95}$ in a 4 to 3 decision ruled in favor of the aborigines Wik and Thayorre Peoples and held that the pastoral leases did not extinguish their native title. In 1994, ${ }^{96}$ the High Court of Australia was called upon by Western Australia to give a ruling on the constitutionality of the National Native Title Act 1993. Its constitutionality was upheld, finding a general power within the "races power" section of the Australian Constitution. ${ }^{97}$ Despite the comprehensiveness of the Act and the willingness of the High Court of Australia to uphold in general the native titles and benefits in favor of aboriginal peoples, one section of the Act, section 12 was struck down "for attempting to convey legislative power upon the judicial branch of the government," by providing that "subject to this Act, the common law of Australia in respect of native title has after 30 June 1993, the force of a law of the Commonwealth."98

If the Australian Judiciary appears to be willing to recognize the rights of the Aborigines almost to the extent of usurping the power of the legislature, it has recognized the Constitutional Supremacy of Parliament as an echo of the English doctrine of Parliamentary Supremacy, the United States Supreme Court cannot be said to be subject to such constitutional constraint. In reality, the United States Courts have been much freer and completely unrestrained in their role as interpreter of United States Constitution and federal legislation. As seen in the Marshall trilogy of judicial decisions, ${ }^{99}$ the U.S. Supreme Court was willing to recognize some indigenous states for Native Americans and their native title. On the legislative front, the battles have not been decisive. As early as 1790, Congress promul-

94. See Racial Discrimination Act, 1975, ch. 52 (Austl.), esp. $\$ 9(1)$. See, however Miller, "Comment, An Australian Nunavut: A Comparison of Inuit and Aboriginal Rights Movements in Canada and Australia," 12 Emory Int'l L. Rev. 1175, 1195 (1998). The Act could hardly be expected to bring racial discrimination to an automatic end.

95. (1996) 141 A.L.R. 129 (Austl.).

96. Western Australia v. Commonwealth (1995) 128 A.L.R. 1,3 (Austl.).

97. Id. at 43-45 and at 62-65. See also U.N. Committee on the Elimination of Racial Discrimination Finding the Native Title Amendment Act, 1998 discriminates against Australian Indigenous land titleholders.

98. See Native Title Act, 1993 , ch. 110 S. 12 . See Western Australia case in 128 A.L.R. 1, 3 (Austl.) at $43-44$ and at $62-65$.

99. See Worcester v. Georgia, 31 U.S. (6 Pet.) 515 (1832). 
gated authority and prohibited unauthorized trade with Indians, ${ }^{100}$ followed by the period of the "reservation era" to force Indian out of their settled area onto confined reservations. ${ }^{101}$ In 1871 , Congress terminated treaty-making with Indians ${ }^{102}$ without abrogating existing treaties. The General Allotment Act (1887) broke up the land held communally by Native Americans into farming and ranching. ${ }^{103}$ Finally, Congress set a program distributing the excess land to nonIndian settlers, thereby reducing the land held by indigenous Indians from 138 million acres in 1877 to 48 million acres in $1934 .{ }^{104}$

The Supreme Court in the Lone Wolf case (1924) ${ }^{105}$ denied injunctive relief requested by the Kiowa and Commanche tribes for violation of Article 12 of the Treaty of Medicine Lodge Creek ${ }^{106}$ in 1946 , the Indian Claims Commission (ICC) was established to process and evaluate the Native American claims against the U.S. Government. The ICC was terminated in 1978, leaving the remaining cases unheard and as the claims became non-compensable under the jurisdiction of the Court of Claims. ${ }^{107}$ In 1955, the Tee-Hit-Ton Indians of Alaska unsuccessfully brought suit against the government to recover compensation for the timber taken from their land. ${ }^{108}$ The Supreme Court reaffirmed that Native Americans' rights to native title were not constitutionally protected property rights and could be extinguished. ${ }^{109}$ The Supreme Court in United States $v$. Sioux Nation of Indians (1980) ${ }^{110}$ extended further the government control over Indians. The shift was from "good faith" to "good faith effort", and the test was exclusively on the legitimacy of the government in its exer-

100. See the Indian Trade and Intercourse Act, 33 Stat. 137 (1790) repealed in 1793.

101. See the Indian Trade and Intercourse Act, ch. 161, 4 Stat. 729 (1834), See Act of March 3, 1871, ch. 120, 16 Stat. 544 (codified and amended 25 U.S.C. $\$ 71$ (1994): hereafter no Indian nation or tribe within the territory of the United States shall be acknowledged as an independent nation, tribe or power with whom the United States may contract by treaty. Id. at 566 .

102. See Act of March 3, 1871, ch 120, 16 Stat. 544 (1871), See Cross, "Sovereign Bargains, Indian Takings and the Preservation of Indian Country in the Twenty-first Century," 40 Ariz. L. Rev. 425, 431 (1998).

103. See General Allotment Act, ch. 119, 24 Stat. 388 (1887).

104. In June 1996, a class action suit was brought by over 300,000 Native Americans alleging mishandling of allotment of land by the federal government from the 1887 General Allotment Act. Cobell v. Babbit, 30 F. Supp. 2d. 24 (D.D.C. 1998), and North Cir. 96-1285, 1999 WL. 607188 at 21 (D.D.C. Aug. 10, 1999).

105. Lone Wolf v. Hitchcock 187 U.S. 553, at 568 (1903).

106. Article 12 of the Treaty requires the consent of three-fourth of the adult males of the Kiowa and Commanche tribes before their land could be taken, Oct. 21, 1867, Articles 12,15 Stat. 581, 585.

107. 25 U.S.C. $\$ 70 \mathrm{v}$ (1978). Only Indian tribes and not individuals were entitled to bring claims before the ICC.

108. 348 U.S. 272 (1955).

109. Id. at $287-88$ and 290 .

110. 448 U.S. 371 (1980). 
cise of plenary power over the Indian land, regardless of the economic losses and hardships suffered by Native Americans. ${ }^{111}$

The future of Native American titles to land appears bleak, in the light of the composition of the current Supreme Court, which appears to be lacking in enthusiasm if indeed not total absence of interest in cases involving native Americans. Native Americans currently exist, like Australian Aborigines, with distinct and independent cultures, with their own customs, traditions, languages, religions and government. But unlike Australia, the United States does not exhibit the same keen sense of political awareness of the need to protect the property rights of indigenous Americans. Lacking the political will within the judicial branch of the government, which is supreme in the United States, very little or nothing by way of positive progressive developments could be expected in the foreseeable future, barring any fundamental change of circumstances bordering a miracle. ${ }^{112}$

It is difficult at this juncture to assess the future status of Native Americans in regard to native title given the lack of the political will on the part of the judiciary to champion the cause of freedom for all without distinction as to races, religions, culture, etc. Comparing recent statistics, Australian Aborigines today have potential claims to seventy-nine percent of Australia's land, ${ }^{113}$ ten years ago their ownership claims were only fourteen percent. ${ }^{114}$ One author comments that the Indians' reliance on the "white man's court" to adjudicate their rights "blunted the capacity" of America's Indigenous peoples for more autonomous form of political action and prevented aboriginal issues from becoming as prominent on U.S. political agenda as they now are in Australia, Canada and New Zealand. ${ }^{115}$ Nor have legal developments in the United States in the field of cultural and religious self-determination been particularly encouraging, having regard to the historical picture of the Christianization efforts and the suppression of indigenous religious ceremonies. ${ }^{116}$ Twentieth-century efforts to vindicate religious rights have not been noteworthy in spite of express provisions in the United States Constitution protecting the

111. Id. at 407-17. Under Federal Indian Policy, "plenary power" means a) exclusive, b) preemptive, and c) unlimited power of congress over the Indians, including their lands and resources.

112. See Getches, "Conquering the Cultural Frontiers: The New Subjectivism of the Supreme Court in Indian Law," 84 Cal. L. Rev. 1573, 1631 (1996); Chief Justice Rehnquist and Justice Stevens appear more disposed to show a serious interest in this area. The willingness of the Supreme Court to provide protection of indigenous interests will be crucial.

113. See Rodriguez, "Note," 23 N.C.J. Int'l. L. \& Com. Reg. 711, 727 (1998).

114. Id. at 711 .

115. See Russel, "High Courts and the Rights of Aboriginal Peoples: The Limits of Judicial Independence," 61 Sask. L. Rev. 247, 267 (1998), at 254.

116. See Dussias, "The Rights to Cultural and Religious Self-Determination: Lessons from the Experience of Native Americans," 2 ILSA J. Int'l \& Comp. L. 633-41 (1996). 
right to free exercise of religion and the American Indian Religious Freedom Act of 1978 (AIRFA). ${ }^{117}$ There is a remote possibility that Native American free exercise claimants may find some relief in future cases under the terms of the Religious Freedom Restructure Act (RFRA) of $1993^{118}$ as a partial response to the Supreme Court decision in Employment Division, Department of Human Resources of Oregon v. Smith. ${ }^{119}$ The 1994 Amendments to AIRFA to ensure lawfulness, under the State and federal law of the ceremonial use of peyote by tribal members ${ }^{120}$ may afford limited protection to the practice of a certain tribal religious ceremony.

One area where progress may be expected in the not too distant future is the process of consultation within the inter-governmental relations committee of the United States on such important matters as the U.N. Draft Declaration on the Rights of Indigenous Peoples. ${ }^{121}$ This practice should be encouraged and the Native Indians of all tribes should be encouraged to participate in the consultation process. It is nonetheless too early to assess the effectiveness of the consultative process..$^{122}$

\section{The Status of Indigenous Peoples In and Outside Their Homelands}

In the preceding section an examination has been made of the status of indigenous peoples who have been subjected to Western invasion and colonization and as a consequence suffered the fate of being the victims of invaders' legal regime in their own birthplace. For the Native American Indians in the North and South American Continents, in the United States, Canada, Mexico, ${ }^{123}$ Peru, ${ }^{124}$ Brazil, ${ }^{125}$

117. 42 U.S.C. $\$ 1996$ (1994); See in particular Lyng v. Northwest Indian Country Protective Association, 485 U.S. 439 (1998) at 453.

118. 42 U.S.C. $\$ 2000 \mathrm{bb}-1$ to $2000 \mathrm{bb}-4$ (1994).

119. 494 U.S. 872 , at $889-890$.

120. 42 U.S.C. $\$ 1996$ a (b)(1) (1994).

121. See, for instance, The Report of the Inter-governmental Relations Committee on Navajo Native Delegation to the Working Group of the U.N. Commission on Human Rights Sixth Session, Geneva, Switzerland, Sept. 6, 2000.

122. A study published in the Annual Survey of Int' 1 and Comparative Law of Golden Gate University recommends that the U.N. allows Iroquois, Cherokee, Navajo, Seminole, and other tribes membership into the United Nations. Some 166,000 Navajos, 43,000 Cherokees and other Indians own more than 96 million acres of land in the United States.

123. See Roberts, "The Protection of Indigenous Populations' Cultural Property in Peru, Mexico, and the United States," 4 Tulsa J. Int'l L., 327 (1997). The United States, Mexico and Peru have become parties to the UNESCO Convention on the Means of Protecting and Preventing the Illicit Import, Export and Ownership of Cultural Property, 1970. 1860 U.N.T.S. 234-236: Cultural property is defined as "property which, on religious or secular grounds, is specially designated by each State as being of importance for archeology, pre-history, history, literature, art or science".

124. Id. See also John E. Conkline, Art Crime 187-88, at 280 (1994).

125. See Suagee, "Human Rights of Indigenous People: Will the United States Rise to the Occasion?," 21 Am. Indian L. Rev. 365 (1997). 
and Ecuador, ${ }^{126}$ or indeed for the restoration of indigenous rights of the aboriginal populations of Australia and the Maoris in New Zealand, ${ }^{127}$ their sufferings have been practically prototype, their status non-existent, their right of access to courts negligible ${ }^{128}$ and legal remedies inconsiderable. ${ }^{129}$ The problems to be addressed in this section concern other regions of the world, where the indigenous or aboriginal populations have continued to coexist and to maintain their distinctive traditional, religious, linguistic and cultural existence within an autonomous, independent sovereign national entity, and universally recognized as such for all times. These indigenous peoples include the Thais, the Chinese and to and appreciable extent the Japanese. Within a long span of time frame, the Thais and the Chinese who are indigenous to East and Southeast Asia, have managed to maintain their distinctive cultures and traditions as well as their continuous political independence, The Japanese have had a much later start and had to contend with pre-existing aborigines and indigenous islanders before their settlement in the main islands of Japan. It is of interest to compare the experience of the Thais with that of the Chinese in their original homelands and the treatment each people received as overseas residents. The Sino-Thai comparison provides an interesting contrast.

\section{A. Indigenous and Overseas Chinese}

The Chinese indigenous populations took millennia and centuries to consolidate the unification of their homeland which is China today through various dynasties and revolutions, including the latest cultural revolution. The different groups of war lords divided and ruled various regions and provinces of China for many long years. All through its national history, China has absorbed within the Celestial Empire countless ethnic Asian and Southeast Asian minorities, among them the Tibetans, the Thais in Yunnan Province (at one time Thai Autonomous State), the Manchus and various Chinese ethnic groups, Cantonese, Taechiew, Hainannese, Hakka, Fukinese, Hunannese, Szechwan, etc. It may be said that today the Chinese indigenous peoples themselves are in power determining their own destinies and not subject to any alien domination or occupation, except for one whole century, China persevered under the regime of

126. See Lopez Bermudez, "Indigenous Peoples and International Law: The Case of Ecuador," St. Thomas L. Rev. Fall (1997).

127. See McHugh, "The Constitutional Role of the Waitangi Tribunal," 3 N.Z.L. Journal 224 (1985). See also Quentin-Baxter, "The U.N. Draft Declaration on the Rights of Indigenous Peoples - The International and Constitutional Law Contexts," 29 Victoria $U$. of Wellington L. R. 85 (1999).

128. See e.g., Santa Clara Pueblo v. Martinez, 436 U.S. 49 (1978).

129. Or indeed unheeded as in Worcester v. Georgia, 31 U.S. (6 Pet.) 515 (1832). 
western extraterritoriality or what the Chinese labeled "unequal treaties".

Within China itself, the Chinese are indigenous and can assert their rights under their own constitution and existing legal regime, affording some measure of protection of the rights of the individuals as a general aspect of human rights rather than the rights of indigenous peoples. However, overseas Chinese, in a way not dissimilar from Indians from Asia, have become minorities in various regions and countries of the world. As members of minorities groups, the rights of overseas Chinese have not always been consistently recognized. For instance, in Thailand, peoples of Chinese descent have long been accepted as assimilated Thais with all the rights and obligations of Thai subjects. They are nevertheless allowed large freedoms to practice their own religions: Confucianism, Buddhism, Taoism, Animism, etc., and to speak and write their own Chinese dialects, subject to one proviso only. No additional Chinese schools or schools in which the medium of teaching is Chinese would be allowed, the Thai Government policy of containing the Chinese or defending indigenous Thai cultures has tolerated no further expansion of Chinese linguistic imperialism. The results have been salutary. The second and third generation Chinese are more conversant with Thai literature than they are at home with Chinese, thus preventing or pre-empting reverse assimilation in cultural transformation. The assimilation policy of the Thai Government has left the cultural traditions of the Chinese virtually intact, while, legally speaking the Thais of Chinese ancestry suffer no social inferiority, nor political disabilities.

The treatment of Overseas Chinese in other countries in Asia have not been as benevolent to the Chinese. In Japan, the Chinese communities minorities sticking together in Yokohama and a handful of other townships, while the use of Kanji in Japanese language has not served as a link to accelerate the assimilation process, one way or another. In other parts of Asia, Chinese minorities are not accorded the most favorable treatment. Outside Asia, in Europe and the United States, "affirmative actions" mean for Chinese, as they do for most Asians, that to survive the Chinese as much as other Asian counterparts have to perform twice or three times better to be accepted as equals. Overseas Chinese and Asian Indians in South Africa, for instance, during the Apartheid regime were separated from Whites and native Africans. Even the legislature had three component parts, according to the colour of their complexion.

\section{B. Thais in Thailand and Other Native Lands}

The Tais or Thais and Chinese are indigenous to East Asian and Southeast Asian regions that for millennia have overlapped. Inevita- 
bly, both have endured the co-existence that has been intermittently peaceful. The Thais were at one time moving southwards from the Yangtse Valley into the Golden Penninsula, split into countless Thai Kingdoms; Nan Chao, Lanna, Lanchang, Shan State, Twelve Panna, Twelve Chu Thai, Saen Wee, Payao, Chieng Mai, Sukhothai, Lopburi, Ayudhaya, Laos, Dien Bien Phu, Assam etc. The main stream little Thais settled in what is known as Thailand today, while other ethnic Thais, including Black Thais and Big Thais, remain in Northern Myanmar, East India and Northern Vietnam. Nanchao kingdom surrendered to one of the three Chinese Kingdoms. Beng Hek annexed Yunnan more than a thousand years ago. ${ }^{130}$

The original Thais in today's Thailand have maintained political independence, sacrificing its outlying tributary provinces to Western colonial powers. As indigenous, the Thais have had to hold their own, and their ground. If Thailand were as large as China and as populous, it would have been less difficult. But with fewer populations and more limited territorial domain, Thailand has succeeded in warding off several waves of Western expansion. ${ }^{131}$ Thus, the problem for the Thais as aborigines and indigenous to the homeland has been how to defend it and how to survive against all odds with distinctive cultures, language and civilization dating back to over 5,000 years of continuous existence.

The problems encountered by indigenous Thais outside Thailand are worth noting. In Yunnan, the Thais received no special treatment as minorities. They were long required to learn Chinese and be assimilated. Yet, through centuries, they managed to maintain their distinct identities as Thais, preserving Thai language, cultures and traditions. During the height of the cold war, Yunnan or formerly Nanchao was upgraded as a Thai Autonomous State, in preparation, as it were, for reunification with the Kingdom of Thailand under Chinese hegemony. Today, the cold war is history and The People's Republic of China is collaborating with its neighbor to the south in more than one way, not least of which is to make Kunming, the capital of Yunnan, a place of touristic attraction for Thai visitors, thereby reducing the tension and pre-empting potential conflicts between the two countries.

Indigenous Thais in other Southeast Asian countries are minorities, except perhaps in Laos where they are integrated majorities, as the Thais and the Laotains are really indistinguishable as Thai-Lao or Siam-Lao ethnic groups. In Shan State, they are minorities of Myanmar and await separation or settlement as their internal political status improves. The Thai-Ahoms in Assam and the Black Thais in

130. See W.A.R. Wood, A History of Siam (1924); and Rong Sayamananda, A History of Thailand, Chulalongkorn (1976).

131. Id. 
Vietnam are integral part of ethnic Thai minorities. Their rights as minorities groups depend on the particular legal systems under which they find themselves.

Within the territory of Thailand today, apart from Chinese minorities, assimilated Chinese Thais and Thai Muslims in the four Southern provinces, in the North and in the central plain, there live several indigenous tribal communities and nomadic hill tribes, such as the Mon-Khmer, the Maew, the Mong, the Karens, the Kachin, the Lasu and rarely the Southern Negritos. Central Government policies towards non-Thai indigenous ethnic minorities have varied from time to time. Currently, freedom of opinion and thought, including freedom of religion and worship seems to be prevailing with the result that secessionist and separatist movements in the South and the Northeast appear to have provisionally subsided. If all the indigenous populations of Thailand who are non-Thai and non-Buddhist can feel socially integrated in a pluralistic society, relative peace and stability will continue to reign. Problems of social and cultural importance exist, however, with regard to a number of "montagnards" or "hill tribes", who move from hillside to another, cutting timber and cultivating opium. Royal projects have been launched with some measure of success to integrate these various ethnic hill tribes.

Other frontier problems relate to the influx of political and economic "refugees" from neighboring countries, Myanmar, Laos, Kampuchea, and Vietnam. These uninvited neighbors are treated as displaced persons or illegal immigrants, and only in exceptional cases where they are sponsored by the Office of the United Nations High Commissioner for Refugees that they are given additional protection. Thailand could not afford to accord all displaced persons the status of "refugees". They are nonetheless indigenous populations of countries adjacent to the Kingdom and include identifiable ethnic groups with existing counterparts in Thailand. Economic and social difficulties notwithstanding, Thailand has agreed to abide by the principle of "non-refoulement", meaning non-repatriation at the frontier. The displaced persons can be admitted into the Kingdom as the country of first refuge, whence they could strive to seek more permanent residence or asylum elsewhere. Such is the plight of various "refugees" who cannot return to their homelands until peace, calm and harmony can be restored.

\section{The Status of Decolonized Indigenous Peoples in Their Native LANDS}

A survey of this nature cannot be complete without reference to the status of countless groups of indigenous populations whose fatherland has been decolonized, but other tribal chiefs have taken the control of the lands once unified under colonial domination. Not un- 
like the richly populated subcontinent of Barata (India), the ethnicity of Nigeria is so vastly divergent that there is no precise definition of Nigeria apart from the geographical location or limits within which Nigeria is situated. ${ }^{132}$

The word "tribe" is hardly appropriate to describe these Nigerian ethnic groups. The Ibo or Igbo and Hausa-Fulani are five to ten million strong for each group. The majority groups consist of the Yoruba and the above two groups. The Hausa-Fulani are made up of two subgroups, the Hausa and the Fulani. In November 1990, an Ogoni Bill of Rights was presented to the Government and People of Nigeria, claiming as the people of Ogoni (Babbe, Gokana, Ken Khana, Nyo Khana and Tai) numbering about half a million people, being a separate and distinct ethnic nationality within the Federal Republic of Nigeria, that in pre-British colonial days they were not conquered or colonized by any other ethnic groups in present day Nigeria. Their complaints related specially to the mining of the Ogoni land in various oil fields providing resources of over 30 billion U.S. dollars from which the Ogoni, who owned the land to which they were indigenous received nothing in return. The Ogoni people have no representation, no pipe-borne water, no electricity, no job opportunity and no social or economic development project of the Federal Government. ${ }^{133}$

Like most indigenous peoples who have been colonized and ultimately liberated, the Ogoni people seek political autonomy, a notion of self-determination, to participate in the affairs of the Republic as a distinct and separate unit. In particular, the Ogoni seek direct representation in all Nigerian national institutions, the use and development of Ogoni language in Ogoni territory and the rights to religious freedom as well as the right to protect the Ogoni environment and ecology from further degradation. In other words, the Ogoni are seeking equal protection and equal treatment as any other ethnic group, equally indigenous to the land within the Republic. The basic issues of the Ogoni case may be summarized to include: (1) their participation in the making of decisions that affect them; (2) the need for improved attention to the development of minority tribes that account for the wealth of the nation; (3) the need to balance economic benefits; (4) the need for the government to exercise restraint in clamping down on Ogoni protests in their demand for increased attention or some basic principles of self-determination; and (5) the recognition and respect for human rights by the Federal Government when dealing with them.

132. See Simon A. Rakov, Vassar College '92 (English 32, Fall 1990). Ethnicity in Nigeria African Postcolonial, in English, in the Postcolonial Web.

133. See The Ogoni Bill of Rights, November 1990, available at http://dawodu.net/ ogonibillofrights. 
Not unlike other indigenous ethnic groups in newly independent countries, the national government is called upon to provide equal care and protection to all peoples, minorities or indigenous, or aborigines or otherwise labeled. The possibility of equitable distribution of wealth depends on the political will of the entire population as well as the farsightedness of the government in power.

\section{Conclustons}

The preceding survey of selected practice in a handful of legal systems can scarcely afford a solid basis for any conclusive report. Suffice it merely to expose comparativists to a far wider spectrum of problems encountered by indigenous populations the world over, ${ }^{134}$ and not confined to the profusion of literature based on Eurocentric experience to redeem the effect of ethnocidal and genocidal measures. No amount of legal or constitutional provisions or safeguards could ensure the actual enjoyment of indigenous rights. Several Westernstyle bureaucratic and administrative obstacles have stood in the way of fruitful implementation of the principles of basic freedoms and fundamental human rights for the indigenous peoples as a collectivity of populations with their distinctive cultural, linguistic, religious and other heritage. It should not be forgotten that indigenous rights are collective as well as individual human rights, and that all human rights entail obligations on the part of the States, at least within their territorial jurisdiction and/or control.

Access to court is a minimum standard, but to what avail if there is no favourable applicable law in place nor willing judges freely to give effect to updated beneficial legal provisions. The decision in Worcester v. Georgia is reminiscent of the need for the willingness on the part of all the agencies, notably the executive branch of the government to enforce the law and judicial decision properly rendered after careful judicial deliberation and formulation.

A sound policy at the national level in favour of the indigenous peoples is indispensable to their survival as distinct and separate but equal ethnic groups. More significant than government policy is the growing consciousness on the part of the bulk of the population represented on the central government, who may feel the urge to share a more liberal outlook. It is the psychology of the mass that deserves a higher level of education to be free from pre-existing bias and prejudices based on ignorance and human greed, and to tolerate and appreciate the existence of the world outside the one in which we live. After all, globalization does not mean the imposition of our world on the outside world. Rather a search should be made better to under-

134. See the trail-blazer in a White Paper by Russel Barsh, in supra n. 11; and the Report of the Working Group on Indigenous Populations, presented by Miguel Alfonso Martinez, President-Rapporteur at the close of the decade, supra n. 2. 
stand the world around us. While the caste system was long abolished under the Indian Constitution, the existence of class distinction still lingers on. One of the lessons that can be learned from this cursory exercise is the apparent potentiality of international efforts which can be orchestrated to substantiate and nourish the common hope for the survival with honour of every living thing on earth, every species of breathing being, a human being, be it or not part and parcel of an indigenous people or aborigines or immigrants or otherwise. If persons are equal individually, they should also receive the same respect and the same treatment collectively as distinct ethnic groups. All things considered and with a balanced approach, every one, every nation, every State should rally in unison to come to rescue and assist all indigenous groups currently in distress in various parts of the globe. Let them have self-determination and the comfort of the freedoms that can be happily shared by all.

Wishful thinking and popular aspirations apart, endeavours should be made to secure the adoption and implementation of the draft U.N. International Bill of Rights for the Indigenous Peoples, who have every where and at all times endured countless and endless sufferings. If everything, good or evil, must come to an end, there should be ways and means of ending these sufferings. With this common resolve, at all levels, international, regional, national, provincial, municipal and village, it becomes transparent that legal development and evolution, in this as well as in all other areas, proceeds within a given time-frame. Thus, the law relating to the status of the indigenous peoples, both international and comparative, can and must be viewed in its proper temporal dimension. What was considered not wrongful yesterday may be prohibited today, such as genocide and ethnocide. What is not yet recognized today may receive general recognition tomorrow, such as the U.N. Draft Declaration on the Rights of the Indigenous Peoples. There is still hope for all, as the applicable law, international and national or comparative, cannot be otherwise than inter-temporal. 